専門医症例報告

すれ違い咬合に対し可撤性部分床義歯を用いて補綴した症例

依田 信裕

\title{
A Case of Non-Vertical Stop Occlusion Rehabilitated Using a Removable Partial Denture
}

\author{
Nobuhiro Yoda
}

抄 録

症例の概要：患者は 71 歳の女性，上下顎部分床義歯の不適合による咀嚼障害を主訴とした。すれ違い咬 合を呈しており, 装着していた義歯は咬合高径の低下と水平的下顎位の偏位, 安定性の欠如が認められた. 治療用義歯により適正な下顎位を回復し，再評価後に支持および把持に留意した最終義歯を装着した。 考察：すれ違い咬合症例においては, 適切な下顎位, 適切な咬合接触による歯列への咬合力の適正配分, ならびに適切な支持および把持によって得られるリジッドサポートが可撤性部分床義歯の安定を得るため に重要であった。

結論：すれ違い咬合症例に対し，適切な咬合とリジットサポートに基づく部分床義歯を適用することで, 良好な治療結果を得た。

和文キーワード

すれ違い咬合，可撤性部分床義歯，下顎位，リジッドサポート

\section{ABSTRACT}

Patient: A 71-year-old female complained of masticatory disturbance resulting from the unconformity of her upper and lower removable partial dentures (RPDs). Non-vertical stop occlusion was observed, and her RPDs were functionally unstable because of the deflected mandibular position including the low occlusal vertical dimension and the inadequate design of the RPDs. The mandibular position was recovered using the treatment RPDs, and definitive RPDs were set after reassessment of her oral conditions.

Discussion: The proper mandibular position, the proper distribution of occlusal force on her occlusal arches by the relevant occlusal contacts and the rigid support design as a result of the proper supporting and bracing elements of the RPDs were fundamental for RPD stability in a case of non-vertical stop occlusion.

Conclusion: This case with non-vertical stop occlusion was successfully rehabilitated using the RPDs supplying relevant occlusal force distribution and function stability.

\section{Key words}

non-vertical stop occlusion, removable partial denture, mandibular position, rigid support 


\section{I. 緒言}

すれ違い咬合症例の補経治療に可撤性部分床義歯を応 用した場合，すべての咬合支持が粘膜支持である義歯床 部とそれに対向する歯根膜支持の歯との間でなされる. そのため粘膜負担が過大となる傾向があり，義歯の安定 不良，義歯床下粘膜の疼痛などの問題を生じることが多 い.す㣗違い咬合症例において可撤性部分床義歯の安定 を得るためには，適切な支持および把持によるリジッド サポート，ならびに適切な咬合付与による歯列への咬合 力の適正な配分が重要となる ${ }^{1)}$.

今回, すれ違い咬合を呈した多数歯欠損症例に対して, これらに留意した可撤性部分床義歯を装着し良好な治療 結果を得たので報告する。

\section{II. 症例の概要}

患者：71歳 (初診時), 女性.

初診: 平成 17 年 7 月.

既往歴：高血圧，左側下肢静脈瘤（平成 15 年摘出術 施行)，僧帽弁閉鎖不全症（平成 17 年 9 月僧帽弁形成 術施行).

現病歴: 初診時の数年前から咬合時 7 の疼痛を自覚 していた。平成 17 年 9 月に僧帽弁閉鎖不全症の手術予 定があり, 術前の口腔内精査のため平成 17 年 7 月に本 院来院. 平成 17 年 8 月に本院口腔外科にて 7 を抜歯後, 義歯増歯修理およびその後の義歯新製を希望し当科を受 診した。

現症：当科初診時の残存歯の歯式は, $\lfloor 7, \overline{6 \uparrow 4}$ で あり，アイヒナー分類 $\mathrm{Cl}$ のすれ違い咬合を呈していた （図 1)。装着していた部分床義歯は義歯設計ならびに義 歯床辺縁形態の不良による支持および把持要素の不足, および咬合接触の両側の不均衡を起因とした機能時の安 定の欠如が認められた。また，下顔面高の減少や口角部 の下垂等の老人様顔貌，義歯人工歯の顕著な咬耗，およ び安静空隙量が $4 \mathrm{~mm}$ と平均的な值 $(2 \sim 3 \mathrm{~mm})$ よ りも大きい所見から，咬合高径の低下が明らかであり， 下顎位も不安定な状態であった。開口障害等は認められ なかったが，開口時下顎はやや右側に偏位した。 6 の 近心には $5 \mathrm{~mm}$ の歯周ポケットが存在し, X 線所見で は垂直性骨吸収が認められ，その他の残存歯には水平性 骨吸収が認められた（図 2)。また，残存歯に対向する 顎堤部には顕著な骨吸収が認められた（図 3).

診断：僧帽弁閉鎖不全症の治療修了後に口腔内診査を 実施し，以下のように診断した。

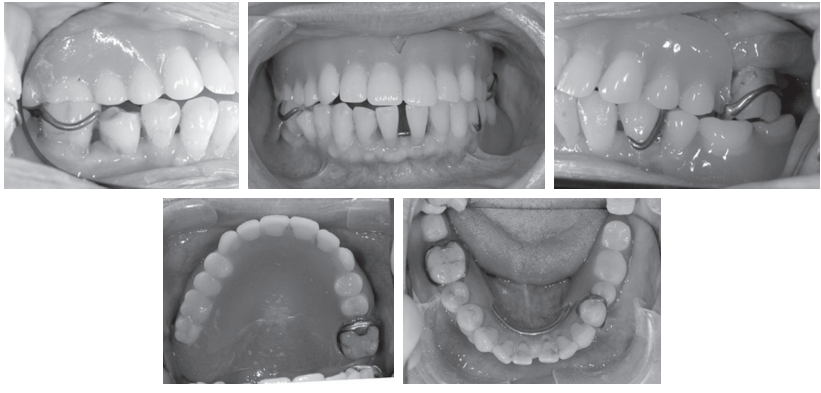

図 1 Oral cavity at first visit 初診時口腔内所見

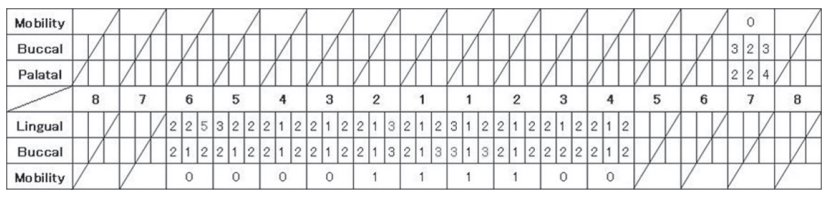

図 2 Periodontal conditions at first visit 初診時歯周組織検査

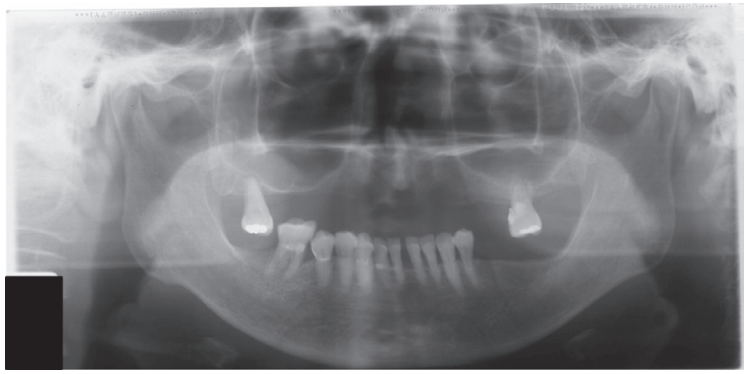

図 3 Orthopantomograph at first examination 初診時パノラマ X 線所見

- 部分床義歯の低位咬合と水平的下顎位の偏位，機能時 の安定不良による咀嚼障害

・慢性辺縁性歯周炎

治療方針：本症例のようなすれ違い咬合に対する欠損 補経治療として可撤性部分床義歯，インプラントを用い た固定性補綴装置およびインプラントを支台としたオー バーデンチャーの3つが考えられ，それぞれ治療方針 を患者に提示した。今回の患者は循環器系の疾患（僧帽 弁閉鎖不全症）の治療を行って間もないこともあり，で きるだけ外科的処置を避けたいとの意向を示したため, 可撤性部分床義歯を用いることで了承を得た。よって治 療方針は以下のように設定した。

(1)残存歯の歯周治療（患者自身のプラークコントロー ルを確立する，歯周病の進行を止める)，(2旧義歯を改 変し，適切な義歯形態・顎間関係・咬合を付与し治療用 義歯として使用，3下顎位および歯周組織状態を再評価 
後に最終義歯を装着, 44義歯メインテナンスおよび歯周 病管理。

\section{III．治療内容と経過}

平成 17 年 8 月に, 口腔外科にて抜歯した 7 部に対す る上顎部分床義歯の増歯修理を行った。僧帽弁閉鎖不全 症の治療後, 平成 17 年 9 月の再来院時に, 治療方針に 対するインフォームドコンセントを行い，まずは残存歯 のブラッシング指導抢よび歯周初期治療を行った。次に 患者が使用していた旧義歯の床辺緑形態を修正し，義歯 咬合面への即時重合レジン添加による咬合挙上および咬 合接触状態の改善を行った（図 4)。このとき，挙上量 は前歯部にて約 $2 \mathrm{~mm}$ となった。治療用義歯の咬合調 整を数回行い, 約 3 力月の経過観察期間を経て, 平成 18 年 4 月の再評価時に機能運動時の義歯の浮き上がり がなく，義歯床適合試験材による客観的評価からも義歯 形態は良好であり, また顔貌所見や安静空隙量評価から 咬合高径が適正で，ライトタッピング位が中心咬合位に 安定して収束することから水平的下㖽位も適正と診断 し, 最終義歯製作へと移行した。このとき，患者のプラ ークコントロールに関しては，技術，モチベーションと もに良好な状態であり, 歯周組織も安定している状態で あった。

最終義歯製作に関しては，まずは支台歯に適切なガイ ドプレーンおよびレストシートを付与し, 付加型シリコ ン印象材を用いて上下顎精密印象採得を行った。超硬石 膏により作業模型を製作し，フェイスボウトランスファ 一法により半調節咬合器 (デナーマーク II) に付着した。 咬合器の顆路調節はチェックバイト法を使用して行い, その後ゴシックアーチのタッピングポイント拉よび治療 用義歯における顎間関係を基潐にし，水平的下顎位を決 定した。最終義歯設計はリジッドサポートに基づき，支

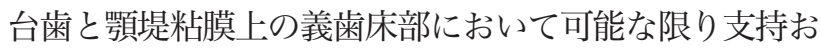
よび把持を確立し, 咬合様式は両側性の平衡咬合を付与 した。平成 18 年 7 月に上下䞄最終部分床義歯を装着し た (図 $5 \sim 7$ ).

最終義歯装着後 3 年経過したが, 上下顎の残存歯に 明らかな歯周組織の変化は認められない（図 8，9）。義 歯の維持安定は良好で会話や食事時においても違和感な く使用している. 現在, 義歯抢よび残存歯の歯周病管理 のために約 3 カ月拉きにメインテナンスを行っている.

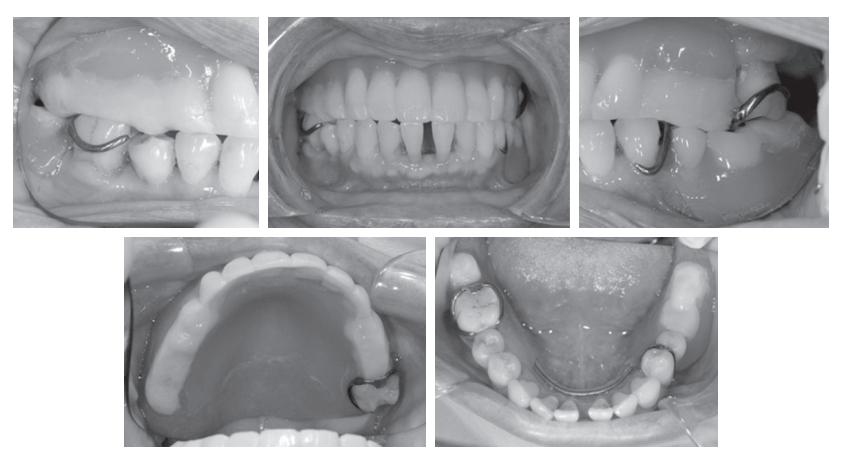

図 4 Intraoral view after treatment denture 治療用義歯装着時の口腔内所見
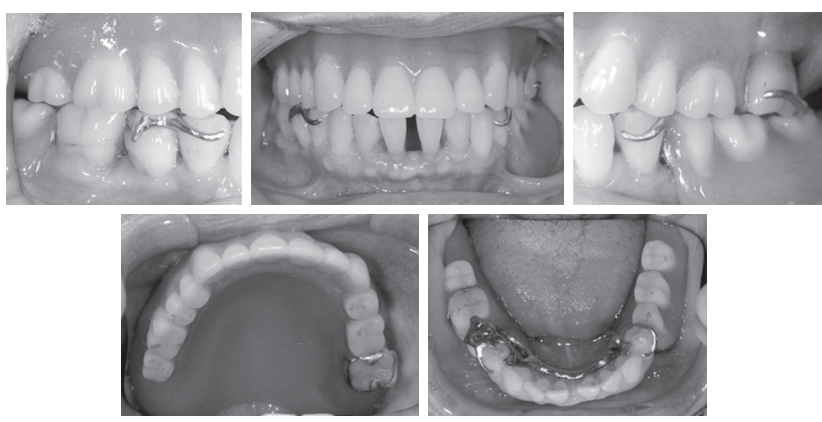

図 5 Intraoral view after prosthetic treatment 補綴治療終了時の口腔内所見

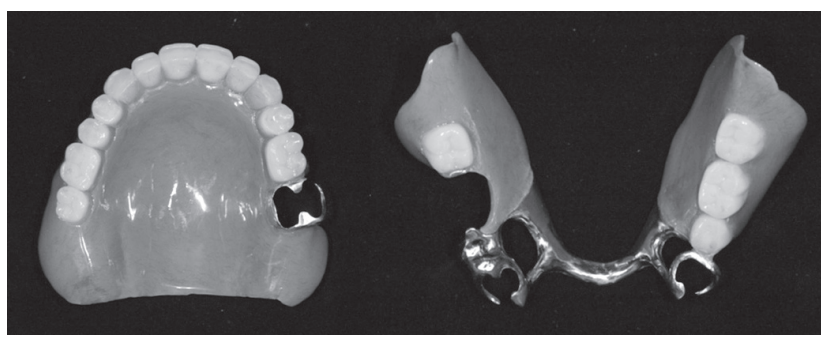

図 6 Definitive dentures 最終義歯

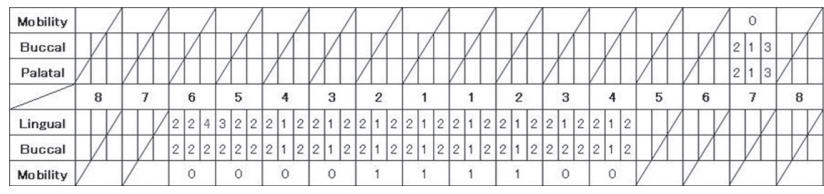

図 7 Periodontal conditions after prosthetic treatment 補経治療終了時の歯周組織検査 

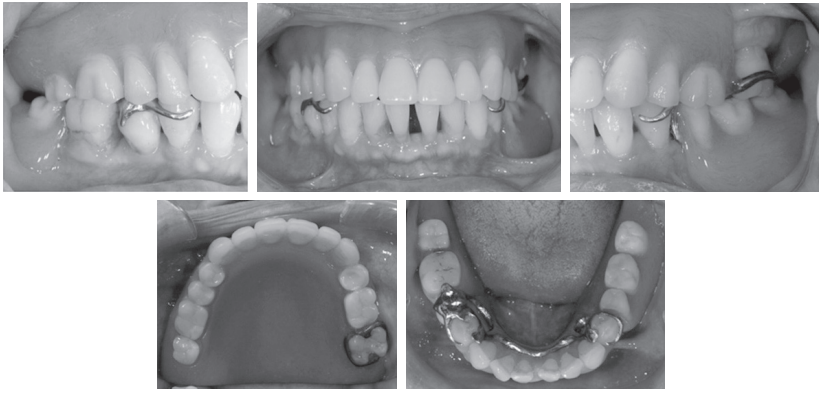

図 8 Intraoral view at 3 years after prosthetic treatment 補綴治療終了 3 年後の口腔内所見

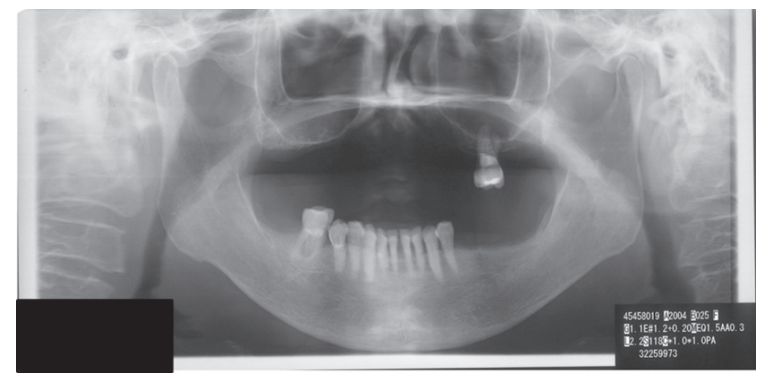

図 9 Orthopantomograph at 3 years after prosthetic treatment 補綴治療終了 3 年後のパノラマ X 線所見

\section{IV 考 察}

\section{1. 咬合力の適正配分}

歯列に咬合力を適切に配分するために，旧義歯を改良 した治療用義歯にて両側の咬合接触のバランスを修正し た。治療用義歯の咬合高径は, 解剖学的指標 (Willis 法, 顔貌所見), 生理学的指標 (安静空隙量), 生理的許容 (患 者のよく咬める感覚）等を総合的に評価し決定した。ま た咬合接触はアップライト位におけるライトタッピング 位の終末位が中心咬合位に安定して収束する状態にて, 左右的および前後的に均等に付与し, 咬合接触点の周囲 $1 \mathrm{~mm}$ 程度まで偏心運動を阻害しないように調整し咬 合接触の均等化を図ることにより，適正な下顎位へと誘 導を試みた ${ }^{2)}$.

\section{2. 最終義歯の設計}

最終義歯製作における咬合採得時のゴシックアーチ描
記において，タッピングポイントの安定性や顎運動の左 右対称性が認められ，治療用義歯により設定した下顎位 および顎機能が啇正であることが確認できた。最終義歯 はリジッドサポートの概念に基づき設計し，上顎は対合 歯列の咬合力に対応するため粘膜支持域を可能な範囲で 大きくし総義歯に近い形態とした ${ }^{3)}$ ，下顎は大連結子に コバルトクロム合金製のリンガルバーを用い，支台装置 は $4 \mid 4$ の舌側全面に把持要素を付与し，5 持および部分的な咬合平面の乱秃を是正することを目的 としてキャップクラスプを用いた。また咬合は可及的に 両側性の平衡咬合を付与した。これらの結果として，最 終義歯は機能時の安定を得ることが可能となり，3 年後 の現在でも良好な状態を保つことができたと考えられる。

\section{3. 残存歯歯周組織}

最終義歯装着時において，残存歯の歯周組織状態は 3 年後の現在でも安定しており，これは歯周基本治療の徹 底，およびリジッドサポートの概念に基づく設計や適切 な咬合力配分により機能時の義歯の動摇を極力抑えたこ とが大きな要因と思われる，今後とも，定期的なリコー ルを継続していく予定である。

\section{V. 結 論}

すれ違い咬合症例に対し，リジッドサポートならびに 適正な咬合力配分により機能的に安定した部分床義歯を 適用することで，良好な治療結果を得た。

\section{文献}

1）尾花甚一，大山喬史，細井紀雄。すれ違い咬合の補綴。 東京 : 医歯薬出版 ; 1994, 2-13.

2）渡辺 誠, 古屋良一, 山下 敦, 野村修一, 古谷野 潔, 佐々木啓一。顎関節症 (Temporomandibular Disorders) の診断と治療 - TMD と咬合一。補綴誌 1997; 41: $1-43$.

3）宮地建夫．欠損歯列の臨床評価と処置方針。東京 : 医歯 薬出版；1998, 61-64.

著者連絡先：依田 信裕

T 980-8575 宮城県仙台市青葉区星陵町 4-1 Tel: 022-717-8369

Fax: 022-717-8371

E-mail: n-yoda@umin.ac.jp 